Vol. 04, No.02, Oktober 2018

Doi: $10.24198 /$ cosmogov.v2i2.xxxxx

\title{
ELIT dan PEMEKARAN DAERAH: Konflik Antar Elit Dalam Proses Pembentukan Provinsi Banten
}

\author{
Neneng Sobibatu Rohmah \\ Program Studi Magister Ilmu Politik \\ Fakultas Ilmu Sosial dan Ilmu Politik (FISIP) Universitas Indonesia \\ Email: nengsobib@gmail.com
}

\begin{abstract}
ABSTRAK
Penelitian ini bertujuan untuk melihat bagaimana konflik yang terjadi antar elit dalam proses pemekaran daerah Banten, siapa sajakah yang terlibat dan bagaimana dinamika yang terjadi. Metode yang digunakan adalah metode kualitatif dengan mendeskripsikan dan eksplorasi dari hasil analisis. Hasil penelitian menunjukkan bahwa terdapat dua kelompok besar elit yang berkonflik dalam proses pembentukan provinsi Banten, yakni: elit Banten dan Elit Jawa Barat. Masing-masing kelompok elit memiliki alasan cukup kuat dalam mempertahankan pendirian. Adapun isu atau faktor yang melatarbelakanginya adalah faktor sejarah, etnik, ekonomi, dan tentu saja politik. Namun, dalam perkembangannya tarik menarik kepentingan dalam proses pembentukan Provinsi Banten ternyata tidak hanya terjadi di tingkat lokal (Jawa Barat dan Banten), tetapi juga di tingkat pusat dalam hal ini elit nasional. Proses pemekaran suatu daerah pada akhirnya sangat berpotensi untuk menimbulkan konflik antara Daerah Induk dengan Daerah Otonom Baru yang teraktualisasikan dalam konflik antar elit politik lokal.
\end{abstract}

Kata Kunci: Pemekaran Daerah; Banten; Konflik Elit.

\section{ABSTRACT}

This study aims to see how the conflicts that occur among the elites in the process of regional expansion Banten, who are involved and how the dynamics that occurred. The method used is qualitative method by describing and exploring from result of analysis. The results showed that there are two major groups of elites conflict in the process of forming Banten province, namely: elite Banten and Elite West Java. Each of the elite groups has reason enough strong in maintaining the establishment. The issues or factors are historical, ethnic, economic, and of course political factors. However, in its development, interest in the process of establishing Banten Province was not only happening at the local level (West Java and Banten), but also at the central level in this case the national elite. The process of division of an area in the end has the potential to create a conflict between the Master Region and the New Autonomous Region which is actualized in the conflict between local political elites.

Keywords: Regional Expansion; Banten; Elite Conflict. 
Vol. 04, No.02, Oktober 2018

Doi: $10.24198 /$ cosmogov.v2i2.xxxxx

\section{PENDAHULUAN}

Salah satu topik sentral pasca reformasi yang masih menjadi perdebatan adalah mengenai permasalahan otonomi daerah yang terjadi di berbagai tempat, baik dalam proses pembentukannya maupun pelaksanaannya. Salah satu dampak mengenai perdebatan otonomi daerah adalah adanya sebuah proses aspirasi dari masyarakat dengan mengupayakan otonomi penuh melalui pemekaran daerah $^{1}$ (Farida, 2010: 215). Upaya masyarakat melalui tuntutannya terhadap pemerintah untuk mendapatkan kewenangan yang lebih luas ini, telah mendapatkan respon yang baik dari pemerintah pusat dengan mengeluarkan UndangUndang No. 22 Tahun 1999 (yang kemudian direvisi menjadi Undangundang No. 32 Tahun 2004) tentang Pemerintah Daerah. Undang-Undang tersebut telah menghadirkan paradigma baru terhadap Pemerintah Daerah untuk dapat mengurus dan menyelenggarakan pemerintahan daerah di Indonesia yang berbasis otonomi yang luas ${ }^{2}$ (Prasojo, 2006:

1 Aulia Farida, dkk, (2010). Pertarungan Gagasan dan Kekuasaan dalam Pemekaran Wilayah, dalam Jurnal Transdisiplin Sosiologi, Komunikasi, dan Ekologi Manusia, h. 33

2 Eko Prasojo dkk, (2006). BluePrint Otonomi Daerah Indonesia, dalam M. Zaki Mubarak dkk. Jakarta: Yayasan Harkat Bangsa, PGRI, dan European Union, h. 117119. Lihat juga Prof. Dr. Djohermansyah Djohan. (2006). lanskap Otonomi Daerah: Analisa dan Kritik, Dalam Indra J. Piliang
117-119). Secara rinci pelaksanaan pemekaran diatur dalam Peraturan Pemerintah (PP) No.78 Tahun 2007 tentang Tata Cara Pembentukan, Penghapusan, dan Penggabungan Daerah.

Gagasan pemekaran daerah yang banyak diusung oleh elit lokal tidak terlepas dari pengaruh demokratisasi dan desentralisasi yang terjadi di Indonesia. $^{3}$ Baik demokratisasi maupun desentralisasi dianggap penting untuk mewujudkan political equity yang akan memberikan kesempatan lebih luas kepada masyarakat untuk berpartisipasi dalam berbagai kegiatan politik di tingkat lokal. ${ }^{4}$ Upaya pemekaran daerah dipandang sebagai sebuah terobosan untuk mempercepat pebangunan melalui pengingkatan kualitas dan kemudian memperoleh pelayanan bagi masyarakat. ${ }^{5}$ Pemekaran daerah pada

dkk, Jakarta: Yayasan Harkat Bangsa, PGRI, dan European Union, h. 153-154

3 Leo Agustino dan Mohammad Agus Yussof dalam tulisan Politik Lokal di Indonesia lebih bersepakat apabila istilah yang digunakan untuk pemekaran daerah adalah redistricting atau penataan ulang wilayah. Namun, apabila pemahaman didasarkan pada hal lain yaitu tumbuhnya daerah baru yang mengharuskan 'mekarnya' (bertambahnya) kuantitas jabatan di daerah, makna pemekaran yang tepat bukanlah 'pemekaran daerah' tetapi 'pemekaran jabatan'.

${ }_{4}$ Leo Agustino dan Mohammad Agus Yussof. (2010). Politik Lokal di Indonesia: Dari Otokratif ke Reformasi Politik, Jurnal Ilmu Politik, Edisi 21, h. 2

${ }^{5}$ Ermaya Suradinata. (2000). Pelaksanaan Otonomi Daerah dalam Kerangka Untuk Meningkatkan Integrasi Bangsa. Jakarta: 
Vol. 04, No.02, Oktober 2018

Doi: 10.24198/cosmogov.v2i2.xxxxx

era reformasi dimulai dari aspirasi elit-elit daerah atau kelompokkelompok masyarakat. Terdapat kecenderungan bahwa pembentukan suatu daerah selalu diawali dengan beranggotakan elit-elit lokal, dilanjutkan dengan penggalangan massa, sebelum akhirnya menyampaikan proposal pemekaran kepada Pemerintah Pusat melalui DPR, Kementerian Dalam Negeri atau Dewan Perwakilan Daerah.

Dalam

proses pembentukannya, pemekaran daerah di beberapa wilayah di Indonesia harus diakui sebagian besar lebih bernuansa politis, hal ini terjadi karena beberapa alasan, sebagian berpendapat sebagai perluasan karir politik, ada juga sebagian yang beralasan sebagai perluasan karir politik. Selebihnya bisa dikatakan dalam rangka mengibarkan bendera partai yang dianut.

Menyoal permasalahan pemekaraan daerah, dapat dijadikan contoh yakni pada saat pembentukan Kabupaten Bandung yang dianggap cukup dekat dengan unsur politis. Kabupaten Bandung Barat secara resmi terbentuk pada tahun 2007 melalui Undang-Undang Nomor 12 tahun 2007 Tentang Pembentukan Kabupaten Bandung Barat. ${ }^{6}$ Namun

Lembaga Ketahanan Nasional, Departemen Pertahanan, h. 10

6 Maman, dkk. (2016). “Agenda Setting dalam Proses Pembentukan Kabupaten Bandung Barat." Dalam Jurnal Ilmu Pemerintahan Cosmogov, Vol. 2 No. 1, h. 92. dalam proses berjalannya pembentukan Kabupaten Bandung Barat tersebut, muncul berbagai agenda dan kepentingan yang dibawa oleh masing-masing elit, baik itu elit birokrat, politisi, kelompok masyarakat hingga pemilik modal. Mereka berlomba-lomba untuk mendapatkan keuntungan bagi mereka masing-masing seperti jabatan dan juga penguasaan proyekproyek pembangunan.

Adanya agenda kepentingan ini menjadikan pemekaran daerah sebagai lahan politis dengan tujuan elit yang justru dapat mendistorsi esensi dari sebuah usaha pembentukan daerah otonom baru, yaitu untuk meningkatkan kesejahteraan masyarakat.

Selain itu, proses pemekaran daerah juga sering menimbulkan konflik antara elit lokal daerah induk dengan elit lokal daerah otonom baru. Beberapa kasus konflik politik elit lokal dalam proses pemekaran daerah antara lain adalah konflik elit lokal Bangka Belitung dengan Sumatera Selatan yang dilatarbelakangi oleh ketidak-relaan hasil pendapatan tambang mereka dibagi dengan provinsi dan kabupaten-kabupaten lain di daratan Sumatera Selatan dan sentimen kedaerahan. Terdapat pula kasus pembentukan Provinsi Irian Jaya Barat, juga menunjukan kecenderungan yang kuat adanya konflik elit di Papua antara yang 
Vol. 04, No.02, Oktober 2018

Doi: $10.24198 /$ cosmogov.v2i2.xxxxx

mendukung pemekaran dengan yang menolak pemekaran.

Selain beberapa kasus di atas, proses pembentukan Provinsi Banten juga menunjukan terjadinya konflik politik antar elit, yakni antar elit lokal Banten berhadapan dengan elit Provinsi Jawa Barat. Elit Banten menginginkan terbentuknya Provinsi Banten, sementara elit Jawa Barat menolak terbentuknya Provinsi Banten. Konflik yang terjadi dalam proses pembentukan Provinsi Banten berpangkal pada perbedaan sikap antara setuju dan tidak setuju Provinsi Banten dibentuk. Pihak Jawa Barat menganggap Banten tidak layak menjadi provinsi sendiri, sementara elit Banten menganggap bahwa Banten layak menjadi provinsi. $^{7}$

Proses pembentukan Provinsi Banten merupakan proses politik yang kompleks dan terjadi konflik politik di antara aktor-aktor yang terlibat di dalamnya. Konflik politik tercermin dari munculnya konflik yang melibatkan elit Banten dan elit Jawa Barat. Pembentukan suatu daerah didasarkan pada UndangUndang yang merupakan keputusan politik dan dapat berlangsung melalui dua mekanisme. Pertama adalah melalui mekanisme pengajuan pemerintah atau inisiatif pemerintah. Kedua adalah melalui mekanisme pengajuan oleh DPR atau inisiatif

7 Jumadi. (2006). Problem Pemekaran Wilayah dan Pembagian Kewenangan. Jakarta: Penerbit YHB Center, h. 235-237
DPR. Proses pembentukan Provinsi Banten dilakukan melalui mekanisme yang kedua, yakni inisiatif DPR. ${ }^{8}$

Gagasan pembentukan suatu daerah otonom baru (pemekaran daerah) mencerminkan kepentingan elit lokal dengan mengangkat isu atau alasan-alasan, yakni alasan sejarah, etnik dan ekonomi. Alasanalasan atau faktor-faktor tersebut sering menjadi sumber konflik antara elit lokal daerah pemekaran dengan elit lokal daerah induk. Konflik politik pembentukan Provinsi Banten tercermin dari sikap pro-kontra terhadap gagasan pembentukan Provinsi Banten. Dalam kasus pembentukan provinsi Banten, ketiga faktor tersebut sering dikemukakan dalam berbagai diskusi dan seminar para elit lokal Banten ketika membahas ide pembentukan provinsi Banten.

Isu yang seringkali dijadikan alasan Jawa Barat untuk menolak pembentukan Provinsi Banten adalah masalah rendahnya kualitas sumber daya manusia. Hal demikian dalam keyakinan masyarakat Banten justru sudah sangat memadai sebagai prasyarat pembentukan provinsi baru. Itu sebabnya ekpose Bappeda Provinsi Jawa Barat yang

Lihat Amandemen UUD Republik Indonesia Tahun 1945, Hak inisiatif adalah salah satu hak yang dimiliki DPR selain hak budget, sebagai bagian dari fungsi membuat UU disamping fungsi kontrol terhadap eksekutif. 
Vol. 04, No.02, Oktober 2018

Doi: 10.24198/cosmogov.v2i2.xxxxx

menunjukkan ketidaklayakan Banten menjadi provinsi telah memancing amarah besar urang Banten. Kesimpulan Bappeda diyakini oleh masyarakat Banten sebagai pesanan politik Gubernur Jawa Barat untuk menjegal aspirasi rakyat Banten.

Di sisi lain, ketidaksetujuan pihak pemda Jawa Barat beralasan dikarenakan adanya kekhawatiran akan hilangnya sumberdaya yang cukup besar. Berkurangnya wilayah dan jumlah penduduk Provinsi Jawa Barat, akan berakibat berkurangnya jumlah Pendapatan Asli Daerah (PAD) dan Dana Alokasi Umum (DAU). ${ }^{9}$ Hal ini lebih jauh akan berpengaruh pada penurunan APBD Jawa Barat. Selama ini Banten merupakan sumber ekonomi bagi Jawa Barat. Kontribusi Banten terhadap perekonomian Jawa Barat pada tahun 1999 sebesar 19 persen. Pada tahun 2000 naik menjadi 23 persen. Selain itu nilai investasi penanaman modal asing (PMA) yang ada di Banten adalah 35 persen dan penanaman modal dalam negeri (PMDN) sebesar 30 persen dari keseluruhan investasi di Jawa Barat. Selain itu tudingan bahwa gagasan pembentukan Provinsi Banten hanya merupakan kemauan segelintir elit Banten juga pernah dilontarkan oleh Jawa Barat.

9 Nina Lubis (2000) dalam Kajian Perkembangan Pembangunan dan Prospek Wilayah Banten, Badan Perencanaan Pembangunan Daerah Provinsi Jawa Barat, 3 Maret, h. 54.
Menghadapi konflik dengan
elit Jawa Barat yang tidak
menemukan titik temu, elit lokal Banten melakukan lobi kepada elit pemerintah pusat dan elit politik di DPR. Hal ini penting untuk mempermudah proses politik yang dilakukan di DPR. Upaya elit Banten meyakinkan pemda Jawa Barat juga dilakukan dengan mengadakan berbagai pertemuan dengan tokoh masyarakat dan elit politik kabupaten/kota lain di wilayah Jawa Barat. Namun pendirian pemda Jawa Barat tetap pada sikap tidak memberikan persetujuan atas usul pembentukan Provinsi Banten. Tentu hal ini semakin menciptakan hubungan yang tidak harmonis dan tegang antara elit Jawa Barat dengan elit Banten.

Proses pembentukan Provinsi Banten merupakan kasus politik lokal yang menarik untuk dikaji lebih mendalam. Hal ini berdasarkan keterlibatan berbagai kelompok elit Banten, Jawa Barat sampai pusat. Kelompok-kelompok elit kemudian terlibat konflik, terutama ketika elit Jawa Barat menolak gagasan pembentukan Provinsi Banten. Hal ini menimbulkan reaksi yang keras dari kelompok elit Banten. Sehubungan dengan itu, menarik meneliti lebih mendalam bagaimana sesungguhnya proses pembentukan suatu daerah otonom baru dalam hal ini proses pembentukan provinsi Banten. Apa masalah yang melatarbelakangi munculnya gagasan 
Vol. 04, No.02, Oktober 2018

Doi: 10.24198/cosmogov.v2i2.xxxxx

dari elit lokal Banten untuk memperjuangkan pemekaran daerah sekaligus menjadi sumber konflik dengan elit Jawa Barat, sejauhmana kelayakan Banten menjadi provinsi dan bagaimana proses politik di DPR. Seperti apa hubungan elit lokal dengan elit nasional terjadi, dan mengapa DPR meloloskan usulan pemekaran daerah. Pertanyaan penelitian yang diangkat dalam penelitian ini adalah: Bagaimana konflik antara elit Banten dengan elit Jawa Barat dalam proses pembentukan provinsi banten?

\section{KERANGKA TEORITIS \\ Perspektif Desentralisasi}

Desentralisasi

dianggap sebagai pilihan yang tepat untuk mengimplementasikan nilai-nilai demokrasi dalam sistem pemerintahan. Menurut Parson, desentralisasi adalah sharing of the governmental power by a central ruling group with other groups, each having authority within a specific area of the state. ${ }^{10}$ Pengertian desentralisasi lainnya, dikemukakan oleh Rondinelli dan Cheema yang menganggap bahwa desentralisasi adalah:

The transfer of planning, decision making, or administrative authority from central government to its field organisation, local administrative units semi autonomous and parastatal

10 Parson sebagaimana dikutip Tim LIPI, Syarif Hidayat dkk,. (2001) Paradigma Baru Otonomi Daerah. Jakarta: P2P LIPI, h. 24 organisation, local government, or non-government organisation. ${ }^{11}$

Konsep desentralisasi mengandung arti adanya proses pelimpahan sebagian wewenang dalam struktur pengelolaan. Pelimpahan sebagian kewenangan ini bisa terjadi dalam wujud kekuasaan atau otoritas sumber daya, dan tanggung jawab yang berasal dari Pemerintahan pusat atau unit di tingkat nasional kepada pemerintah daaerah atau sub-unit dalam pemerintahan. Rondinelli dan Cheema mendefinisikan desentralisasi sebagai transfer perencanaan, pengambilan keputusan dan atau kewenangan administrasi dari pemerintah pusat kepada organisasi pusat di daerah, unit administrasi lokal, organisasi semi otonomi dan parastatal (perusahaan), pemerintahan daerah atau organisasi non pemerintah. ${ }^{12}$

Selanjutnya Rondinelli dan Cheema juga membagi desentralisasi menjadi empat bentuk, yaitu; ${ }^{13}$ (1) Deconsentration, pembagian kewenangan dan tanggung jawab administrasi antara departemen pusat dengan pejabat pusat di lapangan, administration and local administration. (2) Delegation to semi-autonomousand parastatal

\footnotetext{
${ }^{11}$ Rondinelli dan Cheema G.S (ed.). (1983). Decentralization and Development: Policy Implementation in Developing Countries. Beverly Hills: Sage, h. 283

12 Ibid., h. 284

${ }^{13}$ Ibid., h. 285
} 
Vol. 04, No.02, Oktober 2018

Doi: $10.24198 /$ cosmogov.v2i2.xxxxx

organizations, yaitu suatu pelimpahan pengambilan keputusan dan kewenangan manajerial untuk melakukan tugas-tugas khusus kepada suatu organisasi yang tidak secara langsung berada di bawah pengawasan pemerintah pusat. (3) Devolution to local government, pemerintah membentuk unit-unit pemerintah di luar pemerintah pusat dengan menyerahkan sebagian fungsi-fungsi tertentu untuk dilaksanakan secara mandiri. (4) Privatisasi (transfer of functions from government to nongovernment institutions). Privatisasi adalah suatu tindakan pemberian kewenangan dari pemerintah kepada badan-badan sukarela, swasta, dan swadaya masyarakat, tetapi pula merupakan pelebaran badan pemerintah menjadi badan swasta.

\section{Teori Elit}

Perhatian terhadap peran elit politik lokal dianggap penting untuk mengungkap realitas desentralisasi. Teori elit klasik menjelaskan bahwa elit politik merupakan realitas yang ada dalam setiap masyarakat. Menurut Pareto pengertian elit adalah:

Dalam setiap masyarakat diperintah oleh sekelompok kecil orang yang mempunyai kualitaskualitas yang diperlukan bagi kehadiran mereka pada kekuasaan sosial dan politik yang penuh. Merekalah yang dikenal sebagai elit. Elit merupakan orang-orang yang berhasil, yang mampu menduduki jabatan tinggi dalam lapisan masyarakat. Masyarakat terdiri dari 2 kelas: (1) lapisan atas, yaitu elit, yang terbagi ke dalam elit yang memerintah (governing elite) dan elit yang tidak memerintah (nongoverning elite); (2) lapisan yang lebih rendah, yaitu non-elit. ${ }^{14}$

Pendapat hampir sama dikemukakan oleh Gaetano Mosca, yang menjelaskan bahwa:

Dimana lapisan elit yang berkuasa atau disebut classe politica/political elite. Elit politik ini merupakan kelompok terorganisir yang memiliki kewenangan politik. Kelas elit terdiri dari minoritas terorganisir yang akan memaksakan kehendaknya melalui "manipulasi maupun kekerasan", khususnya dalam demokrasi. Elit politik juga menunjukkan semua fungsi politik, monopoli kekuasaan, dan menikmati setiap keuntungan dari kekuasaan. Kekuasaan yang mereka miliki tidak berasal dari komunitasnya atau posisi ekonomi, melainkan dari organisasinya yang berhubungan dengan kekuasaan publik negara. ${ }^{15}$

Berdasarkan pendapat Pareto dan Mosca maka karekteristik yang membedakan elit adalah kecakapan untuk memimpin dan menjalankan kontrol politik, sekali kelas yang

\footnotetext{
${ }^{14}$ Vilfredo Pareto. (1916). The Mind and Society, 4 vols., Arthur Livingstone, New York, Harcourt Brace, Itali, dalam Op.cit, h. 200

15 Gaetano Mosca. (1939). The Rulling Class, hamah D. Khan, penerjemah, Arthur Livingstones, New York: McGraw Hill, dalam Ibid, h. 201-203
} 
Vol. 04, No.02, Oktober 2018

Doi: 10.24198/cosmogov.v2i2.xxxxx

memerintah tersebut kehilangan kecakapannya dan orang-orang di luar kelasnya menunjukkan kecapakan yang lebih, maka terdapat segala kemungkinan bahwa kelas yang berkuasa akan dijatuhkan dan diganti oleh kelas penguasa yang baru (sirkulasi elit).

Dengan

demikian

sesungguhnya dalam proses perjuangan pembentukan Provinsi Banten terdapat pertemuan atau merupakan kolaborasi antara elit lama dengan elit baru di Banten. Dalam setiap kelompok elit Banten, baik Pokja maupun Komite juga terdapat komposisi yang hampir sama, yakni terdapat elit lama dan elit baru. Elit lama dan elit baru dalam pandangan Suzanne Keller merupakan elit stratejik. Menurut Keller selain the ruling class, terdapat elit stratejik yang dibedakan atas dasar cara rekruitmen, organisasi internal, dan tingkat spesialisasinya. Terdapat enterpreneur yang tidak hanya collective actors tetapi juga collective symbols. Keller membedakan tiga level simbol, yaitu simbol kognitif (ilmu pengetahuan dan profesionalisme), simbol moral (nilai-nilai dan tindakan), dan simbol ekspresif (emosi, dan pola perilaku). Enterpreneur bisa hadir dlama bentuk organisasi kepentingan, dan di sisi lain secara simbolik mewakili kewenangan ekonomi, profesionalisme, pengambilan keputusan ekonomi sebagai enterpreneur yang sukses. ${ }^{16}$

\section{METODE PENELITIAN}

Penelitian ini menggunakan paradigma kualitatif. Dimana proses pembentukan Provinsi Banten ini melalui serangkaian kegiatan penelitian yang berupaya untuk memahami, memberi tafsiran pada fenomena yang dilihat dari arti yang diberikan orang kepadanya. Hal ini berarti, penulis mencoba mendeskripsikan fenomena konflik antar elit dalam proses pembentukan Provinsi Banten secara analisis-kritis yang tentu saja dengan melibatkan berbagai bahan empiris, seperti pengalaman pribadi, intropeksi, pengamatan teks sejarah, dan lainlain. ${ }^{17}$

Metode kualitatif sangat cocok digunakan oleh ilmu-ilmu yang menyangkut kemanusiaan karena tujuan utamanya adalah untuk memahami dan mengerti gejala, fakta, realita, dan peristiwa yang dialami oleh manusia. Sebab fakta dan gejala yang terjadi selalu dipahami berbeda oleh yang mengalaminya, dan ada banyak hal dalam kehidupan manusia yang

16 Suzanne Keller. (1995). Penguasa dan Kelompok Elit; Peranan elit-penentu dalam Masyarakat Modern. Jakarta: PT Raja Grafindo Persada, h. 153

${ }^{17}$ Norman K. Denzin dan Yuonna S. Lincoln (Eds). (1990). "Handbook ofQualitative Research.” London: Sage. h. 2. Sebagaimana dikutip oleh Agus Salim. 2000. Teori dan Paradigma Penelitian Sosial. Yogyakarta: Tiara Wacana. h.5-6. 
Vol. 04, No.02, Oktober 2018

Doi: 10.24198/cosmogov.v2i2.xxxxx

hanya dapat dipahami serta dimengerti dan tidak dapat dikalkulasi secara matematis dan statistik. $^{18}$ Penelitian kualitatif, menurut Creswell merupakan suatu pendekatan atau penelusuran untuk mengeksplorasi dan memahami suatu gejala sentral, sehingga perlu mewawancarai peserta penelitian atau partisipan dengan mengajukan pertanyaan umum. ${ }^{19}$

Beberapa kriteria penelitian ini tergolong jenis penelitian kualitatif. Pertama, studi ini mengkonstruksi sebuah realitas sosial. Dalam hal ini ialah penyebab konflik antar elit dalam proses pembentukan Provinsi Banten. Kedua, sebagaimana ciri penelitian kualitatif, konsep-konsep yang ada dalam penelitian ini tidak disusun dalam bentuk variabelvariabel yang jelas sebagaimana lazimnya dalam penelitian kuantitatif. Konsep dalam penelitian ini berbentuk tema-tema. Ketiga, data yang disajikan dalam bentuk narasi atau kata-kata, dan bukan angka. Data-data tersebut berasal dari beberapa dokumen dan hasil wawancara serta data penunjang lainnya.

Penelitian ini menggunakan tipe penelitian eksplanatif, artinya penelitian ini bertujuan untuk menjelaskan fenomena konflik antar elit dalam proses pembentukan

18 J.R Raco. (2010). Metode Penelitan Kualitatif: Jenis, Karakter dan Keunggulannya. Jakarta: PT Grasindo. h. Viii.

${ }^{19} \mathrm{Ibid}, \mathrm{h} .7$.
Provinsi Banten. Penelitian ini dimaksudkan untuk membuat gambaran sistematis yang faktual mengenai data-data dan fakta-fakta sesuai dengan kejadian atau fenomena yang dimiliki melalui penelitian kualitatif, maka akan mempermudah peneliti untuk mengungkap sebab dan alasan yang terjadi dibalik suatu fenomena sosial. Metode ini juga akan memberikan kemudahan kepada peneliti untuk berinterkasi terhadap responden atau narasumber untuk mengumpulkan data-data sebagai bagian dari akurasinya data tersebut untuk dijadikan bahan analisis penelitian.

Dalam hal ini, dikarenakan penelitian ini menggunakan pendekatan penelitian kualitatif, maka data yang dikumpulkan berisi kutipan-kutipan data yang berasal dari naskah sejarah, literaturliteratur, maupun dokumen-dokumen lainnya. Selain itu juga berasal dari sejumlah dokumen tertulis, baik yang diperoleh melalui media cetak maupun media online, dapat berupa foto, dan dokumen lainnya, yang di dalamnya memuat informasi yang berkaitan dengan tema penelitian.

\section{HASIL DAN PEMBAHASAN}


Vol. 04, No.02, Oktober 2018

Doi: 10.24198/cosmogov.v2i2.xxxxx

Konflik Antara Elit Banten dengan Elit Jawa Barat

\begin{tabular}{|c|c|}
\hline \multirow{4}{*}{$\begin{array}{c}\text { Faktor penyebab } \\
\text { konflik antara elit } \\
\text { Banten dengan } \\
\text { elit Jawa Barat }\end{array}$} & Pengelompokan Elit \\
\hline & Faktor Sejarah \\
\hline & Faktor Ekonomi \\
\hline & Faktor Politik \\
\hline & Faktor Etnik \\
\hline
\end{tabular}

Pengelompokan elit dalam proses pembentukan Provinsi Banten dapat terdiri dari yang pro dan kontra, diantaranya:

Pertama, pihak yang pro terhadap pembentukan provinsi Banten adalah kelompok elit informal (masyarakat) Banten, anggota parpol maupun DPRD dan elit Pemerintah Kabupaten/Kota di wilayah Banten, partai politik di tingkat pusat dan dukungan partaipartai politik yang tidak terlepas dari kepentingan mereka untuk memperoleh dukungan suara pada Pemilu tahun 1999. Kedua, pihak yang kontra terhadap pembentukan Provinsi Banten adalah pihak Pemerintah Provinsi Jawa Barat (Gubernur Jawa Barat) dan DPRD Jawa Barat, meskipun pada akhirnya DPRD Jawa Barat mengeluarkan persetujuan terhadap pembentukan Provinsi Banten. Elit Jawa Barat lainnya yang menolak pembentukan provinsi Banten adalah sesepuh Siliwangi dan kalangan militer. ${ }^{20}$

20 H. Mashudi. (1999). Jawa Barat Salah Satu Pilar Persatuan dan Kesatuan Bangsa
Pengelompokan elit Banten dalam memperjuangkan pembentukan provinsi Banten pada awalnya mereka terbelah dalam dua kelompok besar, yakni Kelompok Kerja Pembentukan Provinsi Banten (Pokja PPB) dan Komite Pembentukan Provinsi Banten (Komite PPB). Konflik bersumber dari masalah strategi perjuangan, keduanya saling mengklaim sebagai satu-satunya wadah organisasi perjuangan pembentukan Provinsi Banten yang sah. Pada akhirnya ketengangan antar dua kelompok elit di Banten dapat diselesaikan dengan terbentuknya Badan Koordinasi (Bakor) PPB yang difasilitasi oleh kelompok elit Banten yang berada di Jakarta. $^{21}$

\section{Faktor Sejarah Dalam Konflik Antara Elit Jawa Barat dengan Banten}

Sejarah konflik Jawa Barat dan Banten memiliki akar yang mendalam dan berlangsung lama. Masyarakat Banten merasa memiliki keistimewaan, yaitu tidak pernah menyerah kepada Belanda, pernah berdiri sendiri karena diblokade Belanda sampai mengeluarkan mata uang sendiri pada tahun 1949. ${ }^{22}$ Kemudian, berdiri kekuasaan Islam di Banten yang dalam perkembangan selanjutnya mendesak kekuasaan

dan salah Satu Pilar dari Republik Indonesia, Bagian 4, h. 2

${ }^{21}$ Irsyad Djuwaeli, dalam Op.cit. h. 214

22 Nina Lubis. (2002). Banten dalam Pergumulan Sejarah Sultan, Ulama, Jawara, Jakarta: LP3ES, h. 13-22 
Vol. 04, No.02, Oktober 2018

Doi: 10.24198/cosmogov.v2i2.xxxxx

Kerajaan Sunda sampai akhirnya menumbangkannya sama sekali. Berdirinya Kesultanan Banten merupakan proses penenggelaman sejarah Kerajaan Sunda. Hal ini membuat konflik antara Kerajaan Sunda dengan Kesultanan Banten tak dapat dihindari hingga terjadi peristiwa penyerangan Kesultanan Banten ke Padjajaran pada tahun 1575 yang dalam penyerbuan Banten ke Padjajaran terjadi dalam tiga gelombang besar. ${ }^{23}$

\section{Faktor Etnik Dalam Konflik Antara Elit Jawa Barat dengan Banten}

Alasan lain yang menjadi
faktor pendorong munculnya
gagasan pembentukan Provinsi
Banten adalah masalah perbedaan
etnik yang tercermin dari adanya
anggapan bahwa urang Banten
berbeda dengan urang Sunda.
Meskipun sesungguhnya tidaklah
mudah membedakan orang Banten
dengan orang Sunda. Adanya
diskriminasi etnik dalam posisi-
posisi strategis di jajaran birkorasi
pemerintahan di Banten oleh orang-
orang Priyangan telah memunculkan
anggapan dan perasaan "terjajah"
dalam diri masyarakat Banten.
Dengan jabatan puncak di
pemerintahan daerah yang diduduki
pejabat dari Priyangan
mengakibatkan rekrutmen pegawai
pun banyak dari orang Priyangan
23 Didi Turmudzi. (2002). "Forum
Musyawarah Masyarakat Sunda, Pikrian
Rakyat,"Bandung, Kamis, 17 Pebruari.

juga. Dalam perspektif urang Sunda, sesungguhnya keberadaan Banten merupakan keberlanjutan kerajaan Sunda. Sejarah Banten tidak bisa dilepaskan dari keberadaan sejarah kerajaan Sunda. Banten tidak memiliki pengertian etnik, tetapi hanya berkonotasi wilayah saja. Banten dianggap sebagai bagian yang tidak terpisahkan dari Jawa Barat. Mereka merasa bahwa Banten memiliki sejarahnya sendiri yang berbeda dengan Sunda. Sejarah menunjukan bahwa kelahiran Kesultanan Banten merupakan ancaman keberadaan Kerajaan Sunda.

Faktor Ekonomi Dalam Konflik Antara Elit Jawa Barat dengan Banten

$$
\begin{aligned}
& \text { Selama menjadi bagian } \\
& \text { wilayah Jawa barat, proses } \\
& \text { pembangunan yang berlangsung di } \\
& \text { Banten lebih lamban dibandingkan } \\
& \text { dengan daerah-daerah lainya di Jawa } \\
& \text { Barat. Masyarakat Banten merasa } \\
& \text { lebih termarjinalisasi dan adanya } \\
& \text { ketidakadilan pembangunan } \\
& \text { ekonomi, pendidikan dan sosial. }
\end{aligned}
$$
Kemiskinan struktural sebagai akibat kebijakan yang ditetapkan oleh pemerintah provinsi dan pusat terjadi di wilayah Banten. Tidak hanya kemiskinan struktural, tetapi di wilayah Banten telah terjadi kemiskinan absolute. Padahal masyarakat Banten menganggap wilayahnya kaya akan sumber daya (pelabuhan, cagar alam, bandara, tambang, kawasan wisata). Namun 
Vol. 04, No.02, Oktober 2018

Doi: 10.24198/cosmogov.v2i2.xxxxx

mereka tidak sepenuhnya dapat menikmati kekayaan daerahnya. ${ }^{24} \mathrm{Di}$ lain pihak, keberatan pihak Pemda Jawa Barat terhadap berdirinya Provinsi Banten adalah dikarenakan adanya kekhawatiran akan hilangnya sumberdaya yang cukup besar di Banten. Berkurangnya wilayah dan jumlah penduduk Provinsi Jawa Barat (dengan hilangnya Banten), akan berakibat berkurangnya jumlah Pendapatan Asli Daerah (PAD) dan Dana Alokasi Umum (DAU). Hal ini lebih jauh akan berpengaruh pada penurunan APBD Jawa Barat. Selama ini Banten merupakan sumber ekonomi bagi Jawa Barat.

\section{Faktor Politik Dalam Konflik Elit} Jawa Barat dengan Banten

Selain faktor-faktor yang telah disebutkan, maka ada pula faktor politik yang cukup kentara dalam proses pembentukan Provinsi Banten. Dinamika politik yang terjadi di Jawa Barat pada awalnya dimulai dengan sikap penolakan elit politik Jawa Barat ditandai dengan belum adanya sikap dari DPRD dan Pemda Provinsi Jawa Barat. $^{25}$ Persetujuan DPRD Provinsi Jawa Barat sebagai daerah induk merupakan salah satu syarat administratif yang harus dipenuhi. Elit Jawa Barat terutama sesepuh Siliwangi, kalangan militer dan tokoh masyarakat Sunda lainnya

24 Khatib Mansyur. (2001). Perjuangan Rakyat Banten Menuju Provinsi Catatan Kesaksian Seorang Wartawan, Jakarta: Antara Pustaka Utama, h. 217

${ }^{25}$ Ibid,. h. 208 menolak pemisahan atau pembentukan Provinsi Banten karena mereka mengharapkan agar Jawa Barat tetap dipertahankan keutuhannya. $^{26}$ Proses politik di DPRD Jawa Barat diwarnai dengan persaingan di antara partai politik terutama Golkar dengan PDI Perjuangan. Proses politik pembentukan provinsi Banten diusung oleh Golkar. Golkar ingin mencari dukungan politik karena pada pemilu tahun 1999 perolehan suara Golkar di wilayah Banten menurun, bahkan kalah dibandingkan dengan perolehan suara PDIP.

Sementara terdapat penolakan dari sejumlah elit Jabar, DPRD Jabar belum menentukan sikapnya dan Pemda Jabar juga masih melakukan studi kelayakan, justeru DPR RI telah mengajukan usulan RUU tentang Pembentukan Provinsi Banten. Sikap Pemda dan DPRD Jawa Barat yang menghendaki perlu dilakukannya kajian, perlu mendengarkan aspirasi seluruh masyarakat Jawa Barat tidak hanya masyarakat Banten dan perlu menanyakan seluruh Kabupaten/Kota di Jawa Barat, dianggap sebagai sikap keberatan mereka terhadap pembentukan Provinsi Banten. Apalagi Pemda Jabar mempermasalahkan juga belum terbitnya peraturan pemerintah yang mengatur pembentukan dan

26 Pikiran Rakyat, "Sikap Pemda Jabar Tunggu Hasil Penelitian Bappeda," Bandung: Januari, 2000. 
Vol. 04, No.02, Oktober 2018

Doi: $10.24198 /$ cosmogov.v2i2.xxxxx

pemekaran daerah, dan Dewan Pertimbangan Otonomi Daerah (DPOD) yang diamanatkan undangundang juga belum dibentuk.

Menyikapi permasalahan tersebut, Pemerintah dan Pansus DPR RI melakukan berbagai upaya menyelesaikan berbagai kendala. Pemerintah bertugas dan bertanggungjawab menyelesaikan pembentukan DPOD, sedangkan Pansus DPR RI akan menangani persetujuan dari Pemda dan DPRD Jawa Barat. Pansus DPR RI kemudian melakukan kunjungan kerja ke DPRD Jawa Barat. Proses politik di tingkat pusat dari pengusulan RUU pembentukan Provinsi Banten sampai pengesahan membutuhkan waktu yang cukup lama. Hal ini terjadi karena masalah prosedur dan persyaratan yang belum terpenuhi. Persoalan belum adanya persetujuan dari DPRD dan Pemda Barat, serta kajian yang obyektif sering dijadikan alasan administratif dalam pembahasan RUU Pembentukan Provinsi Banten. Bahkan pemerintah pernah meminta pembahasan RUU tersebut dihentikan. Alasan lain adalah karena belum terbentuknya DPOD yang memiliki kewenangan memberikan masukan kepada Presiden dalam urusan pemekaran daerah. Proses politik menjadi efektif justeru dengan adanya lobi yang dilakukan baik oleh elit politik yang pro pembentukan Provinsi Banten terhadap pihakpihak yang merasa keberatan berkeberatan.
Tarik menarik kepentingan dalam proses pembentukan Provinsi Banten tidak hanya terjadi di tingkat lokal (Jabar dan Banten), tetapi juga di tingkat pusat. Meskipun usul RUU Pembentukan Provinsi Banten telah disetujui oleh semua fraksi di DPR (Fraksi PDI-P, Fraksi Partai Golkar, Fraksi PPP, Fraksi PKB, Fraksi Reformasi, Fraksi PBB, Fraksi PDU, Fraksi TNI/POLRI, Fraksi KKI dan Fraksi PDKB), tetapi dinamika yang terjadi menunjukkan adanya perbedaan sikap di antara fraksifraksi di DPR. ${ }^{27}$

Lobi yang dilakukan elit Banten terhadap elit politik di DPR dianggap merupakan pilihan yang tepat. Hal ini disebabkan kendala yang dihadapi apabila perjuangan membentuk Provinsi Banten tetap menggunakan jalur eksekutif demikian besar dan tidak mencapai kata sepakat dengan elit Jawa Barat. Selain tidak adanya persetujuan dari pihak Provinsi Jawa Barat, hal tersebut akan mempersulit proses di tingkat pemerintah pusat yang menghendaki adanya persetujuan dari Provinsi Induk (Jawa Barat) sebagaimana di atur dalam UU. Nomor 22 tahun 1999 dan PP Nomor 129 tahun 2000. Untuk itu lobi dilakukan terhadap anggota DPR agar menyetujui dan dapat

\footnotetext{
${ }^{27}$ Yaya Mulyana. (2001). "Elite, Masyarakat Sipil dan Politik Lokal (Studi tentang Gerakan Sosial Pembentukan Propinsi Banten)", Tesis, Program Studi Ilmu Politik Program Pascasarjana Universitas Gajah Mada, Yogyakarta, h.47
} 
Vol. 04, No.02, Oktober 2018

Doi: 10.24198/cosmogov.v2i2.xxxxx

mengusulkan RUU inisiatif DPR atas usulan Pembentukan Provinsi Banten. Hal ini terbukti efektif dengan terbentuknya Panitia Khusus Pembentukan Provinsi Banten.

Aspek politik merupakan salah satu faktor terkuat yang mendorong terjadinya konflik antara elit Jawa Barat dengan elit Banten dalam proses pembentukan Provinsi Banten. Sikap kalangan militer, baik sesepuh Siliwangi maupun Fraksi TNI, serta Fraksi PDI-P di DPRD Jawa Barat yang keberatan terhadap pembentukan Provinsi Banten, menunjukan adanya perbedaan kepentingan politik. Perbedaan kepentingan politik antara elit Jabar dengan elit politik di DPR juga mewarnai proses pembentukan Provinsi Banten. Elit politik yang terlibat dalam proses pembentukan Provinsi Banten terdiri dari elit Banten, Elit Jawa Barat dan Elit politik di tingkat pusat. Sikap elit politik ada yang mendukung pembentukan Provinsi Banten, sementara yang lainnya tidak mendukung. Elit politik yang mendukung terdiri dari elit politik Banten. Meskipun diantara elit politik Banten yang mendukung juga terdapat konflik.

Analisa yang dibangun dalam tulisan ini adalah bahwa elit Banten memperjuangkan Provinsi Banten karena memiliki kepentingan politik untuk menduduki posisi-posisi penting nantinya di Pemerintahan Provinsi Banten, dan memperoleh keuntungan ekonomi. Mereka adalah kalangan jawara, birokrat, pengusaha dan politisi. Elit ini dapat dinamakan transacsional elite. Meskipun demikian terdapat elit Banten yang ikut memperjuangkan Provinsi Banten tidak dalam rangka kepentingan politik atau ingin memperoleh sesuatu dari terbentuknya Provinsi Banten. Mereka lebih menjadikan simbol kebajikan, kekuatan moral dan panutan oleh masyarakat. Tidak ada yang dipertukarkan dari tampilnya elit ini dengan hasil yang diperoleh. Kelompok ini adalah para kyai atau ulama. Elit ini masuk kategori transformative elite.

Baik faktor sejarah, etnik, ekonomi maupun politik kesemuanya merupakan faktor-faktor yang mendorong munculnya gagasan pembentukan Provinsi Banten sekaligus menjadi sumber konflik antara elit Banten dengan Jawa Barat. Faktor sejarah menjelaskan bahwa konflik Banten dengan Jawa Barat memiliki akar konflik yang berlangsung lama sejak berdirinya Kesultanan Banten yang kemudiann mengancan eksistensi Kerajaankerajaan Sunda saat itu. Faktor etnik muncul dengan menguatnya identitas etnik Banten yang menganggap etnik Banten berbeda dengan Sunda dengan segala perbedaan nilai dan buadaya yang dimiliki juga mendorong konflik di antara elit Banten dengan Elit Jawa Barat. Ungkapan sering dikemukakan selama proses pembentukan Provinsi 
Vol. 04, No.02, Oktober 2018

Doi: 10.24198/cosmogov.v2i2.xxxxx

Banten adalah "urang Banten berbeda dengan urang Sunda". Konflik etnik ini tercermin dari munculnya diskriminasi penempatan pejabat-pejabat strategis birokrasi di Banten yang diduduki oleh orangorang Priyangan sampai berakhirnya rezim Orde Baru. Faktor ekonomi dilatarbelakangi oleh kesenjangan pembangunan sosial ekonomi di Banten dengan kabupaten/kota lainnya di Jawa Barat. Hal ini memunculkan anggapan adanya ketidakadilan sosial ekonomi yang diterima masyarakat Banten. Hal ini juga mendorong konflik antara Banten dengan Jawa Barat.

Faktor politik terkait dengan keberhasilan elit lokal Banten dalam memanfaatkan momen perubahan kehidupan politik di Indonesia yakni dengan terjadinya demokratisasi. Elit politik Banten memperjuangkan kepentingannya politiknya untuk memperebutkan dan memperkuat sphere of influence dengan membentuk Provinsi Banten, selain kepentingan ekonomi, jabatan dan penguasaan sumber daya lainnya. Selain itu terdapat kepentingan politik dari elit politik nasional, baik dari partai politik (khususnya Golkar) dan presiden, yang mendorong gagasan pembentukan Provinsi Banten sementara pihak Jawa Barat tidak setuju.

\section{KESIMPULAN}

Dari hasil pembahasan dan analisis di atas, maka dapat ditarik kesimpulan terkait konflik antara elit Banten dengan Elit Jawa Barat dalam proses pembentukan provinsi Banten sebagai berikut:

Terdapat pengelompokan elit dalam pembentukan provinsi Banten yang terdiri dari pro dan kontra. Pihak yang pro terhadap pembentukan provinsi Banten adalah kelompok elit informal (masyarakat) Banten, anggota parpol maupun DPRD dan elit Pemerintah Kabupaten/Kota di wilayah Banten. Sedangkan, pihak yang kontra terhadap pembentukan Provinsi Banten adalah pihak Pemerintah Provinsi Jawa Barat (Gubernur Jawa Barat) dan DPRD Jawa Barat. Selain itu elit yang pro pembentukan provinsi Banten juga awalnya mereka terbelah dalam dua kelompok besar, yakni Kelompok Kerja Pembentukan Provinsi Banten (Pokja PPB) dan Komite Pembentukan Provinsi Banten (Komite PPB).

Konflik antar elit dalam proses pembentukan provinsi Banten dapat dipetakan menjadi dua kelompok besar, yakni elit Banten dan elit Jawa Barat. Keduanya, sama-sama memiliki alasan yang kuat dalam mempertahankan kepentingannya dalam pembentukan provinsi Banten. Alasan yang digunakan keduanya adalah karena adanya faktor sejarah, etnik, ekonomi, dan tentu saja politik.

Tarik menarik kepentingan dalam proses pembentukan Provinsi 
Vol. 04, No.02, Oktober 2018

Doi: $10.24198 /$ cosmogov.v2i2.xxxxx

Banten ternyata tidak hanya terjadi di tingkat lokal (Jabar dan Banten), tetapi juga di tingkat pusat. Meskipun usul RUU Pembentukan Provinsi Banten telah disetujui oleh semua fraksi di DPR (Fraksi PDI-P, Fraksi Partai Golkar, Fraksi PPP, Fraksi PKB, Fraksi Reformasi, Fraksi PBB, Fraksi PDU, Fraksi TNI/POLRI, Fraksi KKI dan Fraksi PDKB), tetapi dinamika yang terjadi menunjukkan adanya perbedaan sikap di antara fraksi-fraksi di DPR.

Berdasarkan dengan hasil penelitian mengenai konflik elit dalam pembentukan Provinsi Banten, maka ada beberapa saran yang akan disampaikan, diantaranya:

Masyarakat harus cerdas dan berpendidikan agar mengetahui secara dalam apa yang dibutuhkan di wilayahnya, agar pembentukan Provinsi tidak hanya menjadi unsur politis segelintir elit.

Aktor LSM diharapkan menjadi lembaga yang aktif dalam penanganan politik lokal di daerah.

Pemerintah

mempertimbangkan secara matang, dan mengawasi dengan baik terkait pembentukan Provinsi agar tujuan pembentukan Provinsi sesuai dengan yang direncanakan.

\section{DAFTAR PUSTAKA}

Agustino, Leo dan Mohammad Agus Yussof. (2010). Politik Lokal di Indonesia: Dari Otokratif ke Reformasi Politik, Jurnal Ilmu Politik, Edisi 21.

Farida, Aulia dkk. (2010). "Pertarungan Gagasan dan Kekuasaan dalam Pemekaran Wilayah," dalam Jurnal Transdisiplin Sosiologi, Komunikasi, dan Ekologi Manusia.

Jumadi. (2006). Problem Pemekaran Wilayah dan Pembagian Kewenangan. Jakarta: Penerbit YHB Center.

Keller, Suzanne. (1995). Penguasa dan Kelompok Elit; Peranan elit-penentu dalam Masyarakat Modern. Jakarta: PT Raja Grafindo Persada.

Lubis, Nina. (2002). Banten Dalam Pergumulan Sejaran Sultan, Ulama, Jawara, Jakarta: LP3ES. (2000). Perkembangan Pembangunan dan Prospek Wilayah Banten, Badan Perencanaan Pembangunan Daerah Provinsi Jawa Barat. Maman, dkk. (2016). Agenda Setting dalam Proses Pembentukan Kabupaten Bandung Barat. Dalam Jurnal Ilmu Pemerintahan Cosmogov, Vol. 2 No. 1.

Mansyur, Khatib. (2001). Perjuangan Rakyat Banten Menuju Provinsi Catatan Kesaksian Seorang Wartawan. Jakarta, Antara Pustaka Utama.

Mashudi. (1999). Jawa Barat Salah Satu Pilar Persatuan dan 
Vol. 04, No.02, Oktober 2018

Doi: 10.24198/cosmogov.v2i2.xxxxx

Kesatuan Bangsa dan salah Satu Pilar dari Republik Indonesia, Bag. 4

Mosca, Gaetano. (1939). The

Rulling Class. hamah D.

Khan, penerjemah, Arthur

Livingstones. New York:

McGraw Hill.

Mulyana, Yaya. (2001). Elite,

Masyarakat Sipil dan Politik

Lokal, Studi tentang Gerakan

Sosial Pembentukan Propinsi

Banten. Tesis, Program Studi

Ilmu Politik Program

Pascasarjana Universitas

Gajah Mada, Yogyakarta.

Norman K. Denzin dan Yuonna S.

Lincoln (Eds). (1990).

Handbook of Qualitative

Research. London: Sage.

Pareto, Vilfredo. (1916). The Mind and Society, 4 vols., Arthur Livingstone, New York, Harcourt Brace, Itali.

Prasojo, Eko dkk. (2006). Blue Print Otonomi Daerah Indonesia, dalam M. Zaki Mubarak dkk. Jakarta: Yayasan Harkat Bangsa, PGRI, dan European Union.

Raco, J.R. (2010). Metode Penelitan Kualitatif: Jenis, Karakter dan Keunggulannya. Jakarta: PT Grasindo.

Rondinelli dan Cheema G.S (ed.). (1983). Decentralization and Development: $\quad$ Policy Implementation in Developing Countries. Beverly Hills: Sage.
Suradinata, Ermaya. (2000). Pelaksanaan Otonomi Daerah dalam Kerangka Untuk Meningkatkan Integrasi Bangsa. Jakarta: Lembaha Ketahanan Nasional, Departemen Pertahanan.

Turmudzi, Didi. (2000). Forum Musyawarah Masyarakat Sunda, Pikrian Rakyat, Bandung. 